\title{
Auxin Synthesis in Crown Gall Tumor Tissue: A Comparison of Three Putative Precursors
}

\author{
By \\ FREDERICK S. DAVIES, ${ }^{1}$ SHIAO-LIM CHEN MAU ${ }^{2}$ and LARRY D. NOODÉN \\ Department of Botany, University of Michigan, Ann Arbor, Michigan 48104, U.S.A.
}

(Received June 6, 1974)

\begin{abstract}
Axenic crown gall tumor callus (from Vinca rosea L.) which is known to synthesize its own auxin is able to convert exogenous ${ }^{14} \mathrm{C}$-indole or tryptamine to indoleacetic acid [5.4 and $10 \times 10^{-6}$ $\mu \mathrm{mol} \times \mathrm{h}^{-1} \times(\mathrm{g} \text { fr } \mathrm{wt})^{-1}$ respectively], but little or no ${ }^{3} \mathrm{H}$-tryptophan is converted [less than $6.4 \times 10^{-8} \mu \mathrm{mol} \times \mathrm{h}^{-1} \times$ (g fr wt $\left.)^{-1}\right]$.
\end{abstract}

\section{Introduction}

Although indoleacetic acid (IAA) plays an important role in regulating plant development, and in spite of a large and impressive literature, its biosynthesis in higher plants is still uncertain. The main reason for this uncertainty is the instability of the indoles which are suspected to be precursors of IAA. Studies on cell-free systems are difficult to interpret, because many enzymes such as peroxidase (4), which may not normally be involved in IAA synthesis, can convert tryptophan and other indoles to IAA. In addition, some phenolic compounds present in plants can cause similar conversions $(4,6)$. Such artifactual reactions are less likely to occur in whole organs or whole cells; however, studies on whole cells or organs suffer from the possible influence of epiphytic bacteria, which are very difficult to exclude completely. Even small numbers of epiphytic bacteria can produce relatively large amounts of IAA, and this is especially significant when radioactive IAA precursors are used (2). Thus studies of auxin biosynthesis, particularly those employing radioactive tracers, have been clouded by uncertainty over what is artifact and what is not. In an effort to avoid as many known artifacts as possible, we have studied the ability of a crown gall tumor callus,

${ }^{1}$ Present address: Division of Plant Industry, CSIRO, P.O. Box 1600, Canberra, A.C.T. 2601, Australia.

${ }^{2}$ Present address: Southern Region U.S. Horticultural Research Laboratory, U.S. Dept. of Agriculture, 2120 Camden Rd., Orlando, Fla. 32803, U.S.A. known to be able to synthesize its own auxin and to be axenic (1), to convert 3 putative auxin precursors to IAA.

\section{Materials and Methods}

Culture and incubations: Vinca rosea $\mathrm{L}$. crown gall tumor callus tissue obtained from Dr. A. C. Braun (Rockefeller University, N.Y.) was grown under axenic conditions on a modified White's medium (8). Two pieces of the inocula weighing approximately $2 \mathrm{~g}$ each were cultured in darkness at $25^{\circ} \mathrm{C}$ for a period of one month or until each piece reached a fresh weight of $15-20 \mathrm{~g}$. Thirtyfive $\mathrm{g}$ of this material were then transferred to $50 \mathrm{ml}$ of sterile distilled water containing tryptophan-UL- $\mathrm{H}^{3}$ (750 $\mathrm{mCi} / \mathrm{mmol})$, indole-2- ${ }^{14} \mathrm{C}(8.9 \mathrm{mCi} / \mathrm{mmol})$ or tryptamine${ }^{2-}{ }^{14} \mathrm{C}(8.9 \mathrm{mCi} / \mathrm{mmol})$. Radiochemical purity was checked by paper chromatography as described below. The tumor callus was incubated in a water bath at $25^{\circ} \mathrm{C}$ under constant gentle agitation for a period of $6 \mathrm{~h}$.

Extractions: After incubation, the material was washed 3 times with $100 \mathrm{ml}$ of distilled water; each time the celltissue suspension was centrifuged at about $3000 \mathrm{~g}$ for $5 \mathrm{~min}$. The pellet was removed and ground with mortar and pestle plus a small amount of washed sand at $4^{\circ} \mathrm{C}$ in $15 \mathrm{ml}$ of $0.1 N$ sodium phosphate buffer, $\mathrm{pH} 7.4$, and $0.1 \mathrm{ml}$ of mercaptoethanol. The homogenate was then centrifuged at $0-4^{\circ} \mathrm{C}$ for $10 \mathrm{~min}$ at $10,000 \mathrm{~g}$. After collection of the supernatant, the pellet was resuspended 2 additional times in $15 \mathrm{ml}$ of buffer and centrifuged as above. The 3 supernatants were combined, yielding a total of $65 \mathrm{ml}$. The final supernatant was extracted 3 times with 2 volumes of peroxide-free diethyl ether. The combined ether fractions, designated the neutral ether extract, were evaporated to dryness and redissolved in $2.0 \mathrm{ml}$ of $80 \%$ ethanol. The aqueous phase was divided into 2 equal parts. One portion was acidified to $\mathrm{pH} 3.5$ with $1 \mathrm{~N} \mathrm{HCl}$, and the other was 
adjusted to $\mathrm{pH} 8.5$ with $1 \mathrm{~N} \mathrm{NaOH}$. Each portion was extracted as above with diethyl ether, and the ether phases were combined, evaporated to dryness, and redissolved in $2.0 \mathrm{ml}$ of $80 \%$ ethanol, representing the final acidic and basic ether extracts respectively.

Partitioning tests using ${ }^{14} \mathrm{C}$-IAA were performed to determine the efficiency of our technique for extracting and purifying IAA. Ninety-two per cent of the total counts appeared in the acidic ether extract, $4 \%$ in the neutral and $4 \%$ in the basic fraction. The amount of IAA present in the neutral and basic ether extracts from tissue homogenates was also checked by paper chromatography and found to be negligible.

Chromatography and measurement of the radioactive compounds: $100 \mu \mathrm{l}$ of each final extract was spotted on Whatman no. 1 paper and chromatographed in descending fashion with ${ }^{14} \mathrm{C}$-IAA, ${ }^{14} \mathrm{C}$-indole, ${ }^{14} \mathrm{C}$-tryptamine and ${ }^{3} \mathrm{H}$-tryptophan run in parallel as standards. The solvent systems employed were isopropanol-ammonia-water at $20: 1: 3 \mathrm{v} / \mathrm{v} / \mathrm{v}$ (IPA), and benzene-acetic acid-water at $2: 1: 1 \mathrm{v} / \mathrm{v} / \mathrm{v}$ (BAA). After drying, the developed chromatograms were divided into $2-\mathrm{cm}$ sections, placed in $10 \mathrm{ml}$ of scintillation medium [5.0 g of 2,5-diphenyloxazole (PPO) and $0.30 \mathrm{~g}$ of 1,4-bis-2-(5-phenyloxazolyl) benzene (POPOP) per liter of toluene] and counted on a Beckman LS 100 at an efficiency of about $50 \%$ for ${ }^{14} \mathrm{C}$ and $5 \%$ for ${ }^{3} \mathrm{H}$.

Although the figure and the table contain data from one typical determination, all experiments were done at least twice, and the results agreed to within $15 \%$ of the average.

\section{Results and Discussion}

Figure 1 shows the distribution of various radioactive compounds in the acidic ether extracts along descending chromatograms using IPA and BAA solvent systems. The total cpm in the IAA regions around $R_{\mathrm{f}} 0.29$ in IPA and 0.68 in BAA were divided by the total counts in the centrifuged homogenate, yielding the percentage conversion to IAA (thereby correcting for uptake) given in Table 1 . With ${ }^{3} \mathrm{H}$-tryptophan, these were 0.17 and $0.16 \%$ or less for IPA and BAA respectively. Since there is no clear IAA peak in either chromatogram, there is a question whether or not any ${ }^{3} \mathrm{H}$-labelled IAA is formed. Most of the ${ }^{3} \mathrm{H}$-tryptophan in the supernatant is in the unbound form [soluble in cold $5 \%(\mathrm{w} / \mathrm{w})$ trichloroacetic acid], thus it is not getting tied up in protein as quickly as it enters these cells. The chromatographic patterns of ${ }^{14} \mathrm{C}$-labelled compounds in the acidic ether extract from tissue incubated with ${ }^{14} \mathrm{C}$-indole were different from those observed for tryptophan. The conversion to IAA, calculated in the same manner as above, was considerably higher for indole, 0.67 and $0.65 \%$ with IPA and BAA solvents respectively. ${ }^{14} \mathrm{C}$-tryptamine is metabolized by the crown gall tissue, producing chromatographic profiles similar to those from ${ }^{14} \mathrm{C}$-indole (Figure 1).

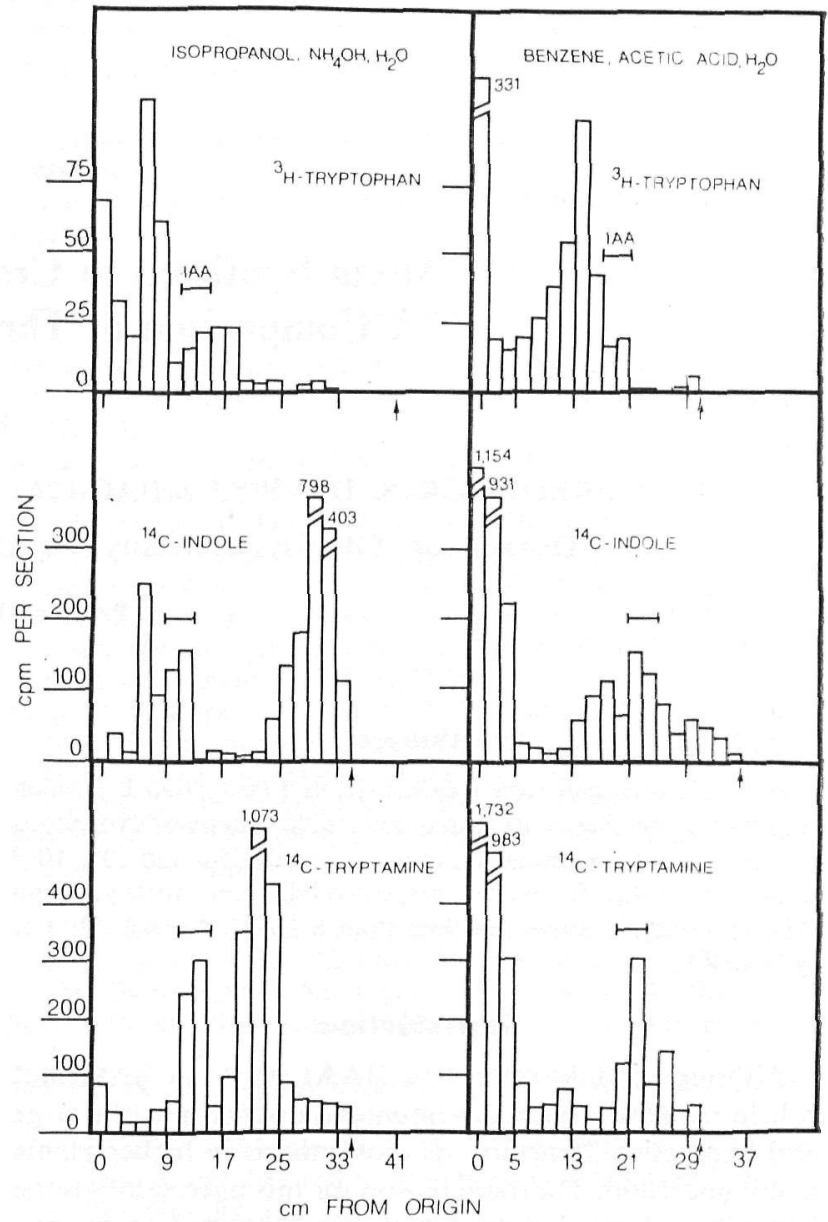

Figure 1. Chromatography of the acidic ether extracts obtained from Vinca rosea crown gall tumor tissue incubated with the radioactive precursor designated on each graph for $6 \mathrm{~h}$. The horizontal bar on each chromatogram indicates the expected location of IAA. The chromatograms on the left were run in isopropanol, $\mathrm{NH}_{4} \mathrm{OH}, \mathrm{H}_{2} \mathrm{O}$ (IPA) and on the right in benzene, acetic acid, $\mathrm{H}_{2} \mathrm{O}$ (BAA). The arrows under each graph designate the solvent front.

${ }^{14} \mathrm{C}$-IAA is formed; however, the conversion percentage (averaging $0.80 \%$ ) is greater than observed for either tryptophan or indole. Thus both indole and tryptamine are clearly converted to IAA, but the conversion of tryptophan is uncertain. It is noteworthy that chromatograms developed in 2 different solvent systems show similar amounts of conversion.

The difference in the ability of crown gall tissue to convert the 3 exogenous radioactive precursors to IAA is most pronounced when the conversion rates are compared on a micromolar basis. The rates are $1.0 \times 10^{-5}, 5.4 \times 10^{-6}$ and less than $6.4 \times 10^{-8} \mu \mathrm{mol} \times \mathrm{h}^{-1} \times(\mathrm{g} \text { fresh weight })^{-1}$ fresh weight for tryptamine, indole and tryptophan respectively (Table 1 ). Since these rates do not take into 
Table 1. Quantitative comparison of the conversion of labelled precursors to indoleacetic acid. IPA and BAA chromatography solvents.

\begin{tabular}{l|c|c|c}
\hline Precursor & $\begin{array}{c}\text { Conversion to IAA, \% } \\
\text { of the radioactivity taken } \\
\text { up }\end{array}$ & $\begin{array}{c}\text { Rate of conversion } \\
\text { to IAA, } \\
\mu \mathrm{mol}^{-1} \times(\mathrm{g} \mathrm{fr} . \\
\mathrm{wt})^{-1}\end{array}$ & \\
\cline { 2 - 3 } & IPA & BAA & \\
\hline${ }^{3} \mathrm{H}$-tryptophan & 0.17 & 0.16 & $6.4 \times 10^{-8}$ \\
${ }^{14}$ C-indole & 0.67 & 0.65 & $5.4 \times 10^{-6}$ \\
${ }^{14}$ C-tryptamine & 0.91 & 0.69 & $1.0 \times 10^{-5}$
\end{tabular}

account the endogenous, non-radioactive precursors, these rates represent minimal rather than the absolute endogenous fluxes. Nonetheless, these results support the earlier conclusion of Winter (6) and Thimann and Grochowska (5) that tryptophan is normally not a direct precursor of IAA in plants, rather tryptamine and/or indole are direct precursors of IAA. In contrast, studies which show tryptophan conversion to IAA are too numerous to recount here [see (3) for a summary], but it is not possible to rule out conversion by small numbers of epiphytic bacteria or other artifacts mentioned above even though some precautions were taken.

Although the data reported here do not resolve the problem of how IAA is synthesized, they cast some doubt on tryptophan as a direct precursor of IAA, at least in this crown gall tissue. They favor tryptamine and indole, and they illustrate a system which could be very useful in elucidating the pathway of IAA synthesis in higher plants.
This represents part of a project which was discontinued in this laboratory in May 1971.

We thank Dr. Armin Braun for supplying the crown gall tumor callus and Dr. William Purves for his helpful comments on the manuscript.

\section{References}

1. Braun, A. C. 1962. Tumor inception and development of crown gall disease. - Annu. Rev. Plant Physiol. 13: 533-558.

2. Libbert, E., Manteuffel, R. \& Siegl, E. 1970. Interactions between plants and epiphytic bacteria regarding their auxin metabolism. IX. The influence of the epiphytic bacteria on the auxin production from tryptophan applied to corn shoots and coleoptiles. - Physiol. Plant. 23: 784-791.

3. Schneider, E. A. \& Wightman, F. 1974. Metabolism of auxin in higher plants. - Annu. Rev. Plant Physiol. 25: 487-513.

4. Shantz, E. M. 1966. Chemistry of naturally occurring growth regulating substances. - Annu. Rev. Plant Physiol. 17: 409-438.

5. Thimann, K. V. \& Grochowska, M. 1968. The role of tryptophan and tryptamine as IAA precursors. - In Biochem. and Physiol. of Plant Growth Substances. (F. Wightman, and G. Setterfield eds.), pp. 231-242. Runge Press, Ltd., Ottawa.

6. Wheeler, A. W. \& King, H. G. C. 1968. Conversion of tryptophan to auxin by phenolic esters from dwarf French bean (Phaseolus vulgaris). - Phytochemistry 7: 1057-1063.

7. Winter, A. 1966. A hypothetical route for the biogenesis of IAA. - Planta 71: 229-239.

8. Wood, H. N. \& Braun, A. C. 1965. Studies on the net uptake of solutes by normal and crown-gall tumor cells. — Proc. Natl. Acad. Sci. U.S. 54: 1532-1538. 
This document is a scanned copy of a printed document. No warranty is given about the accuracy of the copy. Users should refer to the original published version of the material. 